Journal of

Synchrotron

Radiation

ISSN 0909-0495

Received 24 May 2010

Accepted 7 September 2010

\section{Optimization of salt concentration in PEG-based crystallization solutions}

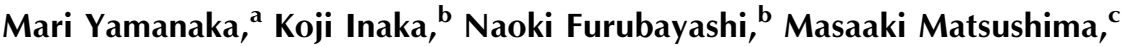 \\ Sachiko Takahashi, ${ }^{a}$ Hiroaki Tanaka, ${ }^{a} *$ Satoshi Sano, ${ }^{d}$ Masaru Sato, ${ }^{d}$ \\ Tomoyuki Kobayashid and Tetsuo Tanaka ${ }^{d}$
}

${ }^{\mathbf{a} C o n f o c a l}$ Science Inc., Japan, ${ }^{\mathbf{b}}$ Maruwa Foods and Biosciences Inc., Japan, ${ }^{\mathbf{c}}$ Aino Gakuin College, Japan, and Japan Aerospace Exploration Agency, Japan. E-mail: tanakah@confsci.co.jp

\begin{abstract}
Although polyethylene glycol (PEG) is the most widely used precipitant in protein crystallization, the concentration of co-existing salt in the solution has not been well discussed. To determine the optimum salt concentration range, several kinds of protein were crystallized in a 30\% PEG 4000 solution at various $\mathrm{NaCl}$ concentrations with various $\mathrm{pH}$ levels. It was found that, if crystallization occurred, the lowest effective salt concentration depended on the $\mathrm{pH}$ of the protein solution and the $\mathrm{pI}$ of the protein molecule; that is, higher salt concentrations were required for crystal growth if the difference between $\mathrm{pH}$ and $\mathrm{pI}$ was increasing. The linear relationship between the charge density of the protein and the ionic strength of the crystallization solution was further verified. These results suggested that the lowest effective concentration of salt in a crystallization solution can be predicted before performing a crystallization experiment. Our results can be a tip for tuning crystallization conditions by the vapor-diffusion method.
\end{abstract}

Keywords: protein crystallization; optimization; salt concentration; polyethylene glycol; ionic strength.

\section{Introduction}

The success rate of screening for suitable protein crystallization conditions is often low owing to the extensive number of variables that can be altered, such as the amount and types of salt, buffer, $\mathrm{pH}$, precipitants and other chemical components (Cudney et al., 1994). Based on the review by Chayen \& Saridakis (2002), from cloned protein to structure determination the largest failure rate is in obtaining good crystals, but little attention has been given to improving methods of optimization of crystallization conditions.

Polyethylene glycol (PEG) is a frequently used precipitant reagent in protein crystallization solutions. Bonneté (2007) reported that the concentration of salt was limited to roughly $300 \mathrm{~m} M$ when salt and polymer were both used and that there were some synergetic effects between polymer and salt. It was considered that low salt concentrations screened the macromolecular charges and decreased the electrostatic repulsive force between the molecules. However, the salt concentration required to screen and to grow a crystal has not been studied yet.

In this report we show the results of experiments to determine the concentration range of salt in PEG solutions at several $\mathrm{pH}$ levels which can be used to grow crystals, and discuss the results from the charge density viewpoint, proposed by Matsushima \& Inaka (2007). We found that there is a good linear relationship between the charge density of the macromolecule and the ionic strength of the reservoir solution.

\section{Materials and methods}

\subsection{Crystallization}

A counter-diffusion method (García-Ruiz \& Moreno, 1994; Otálora et al., 2009) was used here because it could control better the concentrations of the chemicals in the solution by a simpler diffusive process than the vapor-diffusion method, although the vapor-diffusion method is widely used for protein crystallization by most crystallographers. We use a gel-tube method (Tanaka et al., 2004), which is a modification of the original capillary counter-diffusion method of García-Ruiz \& Moreno (1994). Assembly of the crystallization device has been described previously (Tanaka et al., 2004). Briefly, a $0.3 \mathrm{~mm}$-diameter capillary was filled with protein solution to a length of $30 \mathrm{~mm}(2.1 \mu \mathrm{l})$ and its upper end was sealed with clay before being plugged with a silicone tube filled with agarose gel, the length of which was $5 \mathrm{~mm}$. The capillary was placed into the test tube in which $3 \mathrm{ml}$ of reservoir solution was loaded. The gel allowed components of the protein and 
reservoir solutions to diffuse through each other. Agarose gel in the tube was pre-equilibrated with respective reservoir solutions. The crystallization was performed at $293 \mathrm{~K}$ for two weeks and checked on days 1,2,3,7 and 14 by microscope. At least two capillaries were used for respective crystallization conditions.

\subsection{Proteins}

The proteins, hen egg-white lysozyme (Seikagaku), $\alpha$-amylase derived from Aspergillus oryzae (Shinnihon Chemicals) and glucose isomerase (Hampton Research), were chosen based on availability and crystallizability. The proteins were further purified: lysozyme by CM-TOYOPEARL (TOSO), $\alpha$-amylase and glucose isomerase by $\mathrm{Q}$ Sepharose HP (GE Healthcare). The purified proteins showed a single band through SDSPAGE and native-PAGE. Finally, $30 \mathrm{mg} \mathrm{ml}^{-1}$ lysozyme in $50 \mathrm{~m} M$ acetate buffer $\mathrm{pH} 4.5$, $30 \mathrm{mg} \mathrm{ml}^{-1} \alpha$-amylase in $50 \mathrm{~m} M$ Tris- $\mathrm{HCl} \mathrm{pH}$ 7.5 and $20 \mathrm{mg} \mathrm{ml}^{-1}$ glucose isomerase in $20 \mathrm{~m} M$ Tris- $\mathrm{HCl}$ and $200 \mathrm{~m} M \mathrm{NaCl} \mathrm{pH} 7.5$ were prepared.

\subsection{Reservoirs}

Several series of reservoir solutions, which were a mixture of $30 \%$ PEG 4000 as a precipitant, $\mathrm{NaCl}$ of $0 \mathrm{~m} M$ to $700 \mathrm{~m} M$ as a salt, and several kinds of buffers including $50 \mathrm{~m} M$ acetate buffer at $\mathrm{pH} 4.5$ and 5.5, $50 \mathrm{~m} M$ HEPES-NaOH at $\mathrm{pH} 7.0$ and $50 \mathrm{~m} M$ Tris- $\mathrm{HCl}$ at $\mathrm{pH}$ 9.0, were prepared (Table 1).

\subsection{Calculation}

To determine the concentration profile of $\mathrm{NaCl}$ and PEG 4000 in the capillary tubing and the gel, the concentration change was calculated by one-dimensional simulation (Tanaka et al., 2004) using diffusion constants of $1.2 \times 10^{-9} \mathrm{~m}^{2} \mathrm{~s}^{-1}$ and $0.16 \times 10^{-9} \mathrm{~m}^{2} \mathrm{~s}^{-1}$, respectively.

The ionic strengths of the reservoir solutions were calculated using $\mathrm{p} K_{a}$ values of acetate, HEPES and Tris buffers of $4.80,7.55$ and 8.06 , respectively, and the $\mathrm{NaCl}$ concentration in each solution. The $\mathrm{pI}$ of the proteins was calculated using $\mathrm{p} K$ values of amino acids derived from the report of Sillero \& Maldonado (2006).

The charge density, which is the amount of charge normalized to the protein molecular volume, was calculated using the following equation, which was proposed by Matsushima \& Inaka (2007),

$$
\text { Charge density } \begin{aligned}
(M) & =\frac{\text { Number of charges }}{\text { Volume for one protein }} \\
& =\frac{\text { Number of charges } \times 10^{27}}{V_{\mathrm{M}} \times \mathrm{MW} \times 6.02 \times 10^{23}} .
\end{aligned}
$$

The number of charges is the net amount of charge of one protein molecule at a certain $\mathrm{pH}$. It is calculated using the amino acid composition and the $\mathrm{p} K$ values of amino acids. $V_{\mathrm{M}}$ is Matthew's coefficient which is already deposited in the Protein Data Bank. MW is the molecular weight of the protein molecule calculated using the amino acid composition.

\section{Results}

The crystallization results are summarized in Table 2. The appearance of crystals, oil and precipitate observed at day 14 are indicated. More than two capillaries were used and crystallization was observed reproducibly for each crystallization condition.

In the experiments with lysozyme with buffer solution $\mathrm{pH}$ 4.5 , protein solutions in the capillaries were still clear even at day 14 with $0 \mathrm{~m} M$ to $300 \mathrm{mM} \mathrm{NaCl}$. With $400,500,600$ and $700 \mathrm{~m} M \mathrm{NaCl}$, crystals were observed at days $14,7,3$ and 2, and they grew at the position 11-30, 8-12, 5-25 and 4-30 mm, respectively, from the gel-tube site of the capillaries at day 14 .

For lysozyme with buffer solution $\mathrm{pH}$ 7.0, protein solutions in the capillaries were still clear even at day 14 with $0 \mathrm{~m} M$ to $200 \mathrm{~m} M \mathrm{NaCl}$. With 300, 400, 500, 600 and $700 \mathrm{mM} \mathrm{NaCl}$, crystals were observed at days 14,14, 7, 7 and 7, and they grew at the position $20,8-26,5-18,0-30$ and $17-30 \mathrm{~mm}$, respectively, from the gel-tube site of the capillaries at day 14 (Fig. 1).

For $\alpha$-amylase with buffer solution $\mathrm{pH} 5.5$, protein solution in the capillaries was clear even at day 14 with $0 \mathrm{mM} \mathrm{NaCl}$. A cluster of rod-shaped crystals appeared at day 1 with $100 \mathrm{mM}$ and $200 \mathrm{mM} \mathrm{NaCl}$. With $300 \mathrm{mM} \mathrm{NaCl}$, a cluster of rodshaped crystals appeared in one capillary (Fig. 2) and oil was observed in the other capillary at day 1 . With $400 \mathrm{mM} \mathrm{NaCl}$, oil appeared at day 1 . In those capillaries with $300 \mathrm{mM}$ or $400 \mathrm{mM} \mathrm{NaCl}$ in which oil was observed, a cluster of rod- 


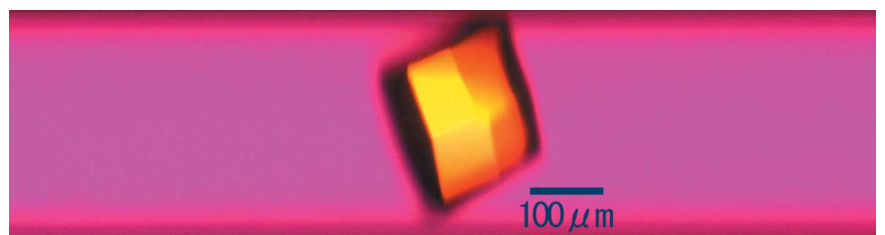

Figure 1

Crystal of lysozyme. A crystal was obtained in $50 \mathrm{~m} M$ HEPES $\mathrm{pH} 7.0$ with $30 \%$ PEG 4000 and $700 \mathrm{mM} \mathrm{NaCl}$. It was observed 7 days after the sample loading.

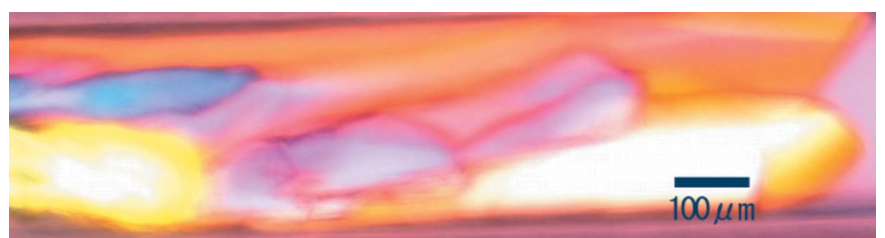

Figure 2

Crystal of $\alpha$-amylase. A cluster of rod-shaped crystals of $\alpha$-amylase was obtained in $50 \mathrm{~m} M$ acetate buffer pH 5.5 with $30 \%$ PEG 4000 and $300 \mathrm{~m} M \mathrm{NaCl}$. It was observed 7 days after the sample loading.

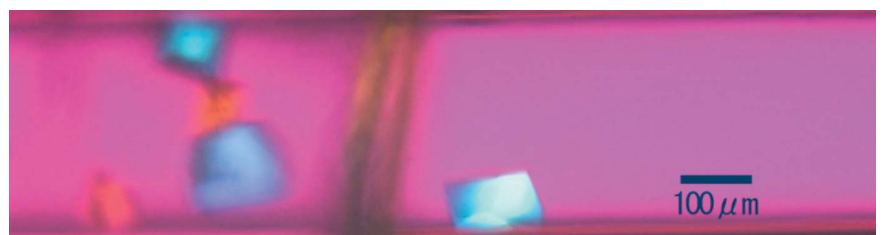

Figure 3

Crystal of glucose isomerase. Crystals of glucose isomerase were obtained in $50 \mathrm{~m} M$ Tris- $\mathrm{HCl}$ buffer $\mathrm{pH} 9.0$ with $30 \%$ PEG 4000 and $500 \mathrm{mM} \mathrm{NaCl}$. They were observed 1 day after the sample loading.

shaped crystals appeared at day 7. At day 14, the clusters of crystals were observed at the position $0-5 \mathrm{~mm}$ from the geltube site of all the capillaries with 100, 200 and $300 \mathrm{mM} \mathrm{NaCl}$. With $400 \mathrm{mM} \mathrm{NaCl}$, crystals and oil were observed at the same position.

For $\alpha$-amylase with $\mathrm{pH} 7.0$, the protein solution was clear with $0 \mathrm{~m} M$ and $100 \mathrm{~m} M \mathrm{NaCl}$ even at day 14 . Oil appeared at day 1 with $200 \mathrm{~m} M$ to $700 \mathrm{~m} M \mathrm{NaCl}$. After the appearance of oil, at day 3, a cluster of rod-shaped crystals appeared with $200 \mathrm{~m} M$ and $300 \mathrm{~m} M \mathrm{NaCl}$. At day 14, the crystals and/or oil were observed at the position $0-2,0-4,0-8,0-8,0-9$ and $0-$ $9 \mathrm{~mm}$ from the gel-tube site of the capillaries with 200,300, $400,500,600$ and $700 \mathrm{mM} \mathrm{NaCl}$, respectively.

For $\alpha$-amylase with $\mathrm{pH}$ 9.0, the protein solution was clear with $0 \mathrm{~m} M$ and $100 \mathrm{~m} M \mathrm{NaCl}$ even at day 14 . Oil appeared at day 1 with $200 \mathrm{~m} M$ to $700 \mathrm{~m} M \mathrm{NaCl}$ without crystals until day 14 at the position $0-5 \mathrm{~mm}$ from the gel-tube site of all the capillaries with 200, 300, 400, 500, 600 and $700 \mathrm{mM} \mathrm{NaCl}$.

With glucose isomerase at $\mathrm{pH} 7.0$ and $\mathrm{pH} 9.0$, the protein solution was clear in the solution with $0 \mathrm{mM}$ and $100 \mathrm{mM}$ $\mathrm{NaCl}$ even at day 14 . But many small crystals appeared at day 1 in all of the capillaries (Fig. 3) with $200 \mathrm{~m} M$ to $700 \mathrm{~m} M \mathrm{NaCl}$. All of them were accompanied by precipitate except for $200 \mathrm{mM} \mathrm{NaCl}$ at $\mathrm{pH}$ 9.0. At day 14, the crystals were observed at the position 0-2 $\mathrm{mm}$ from the gel-tube site of the capillaries
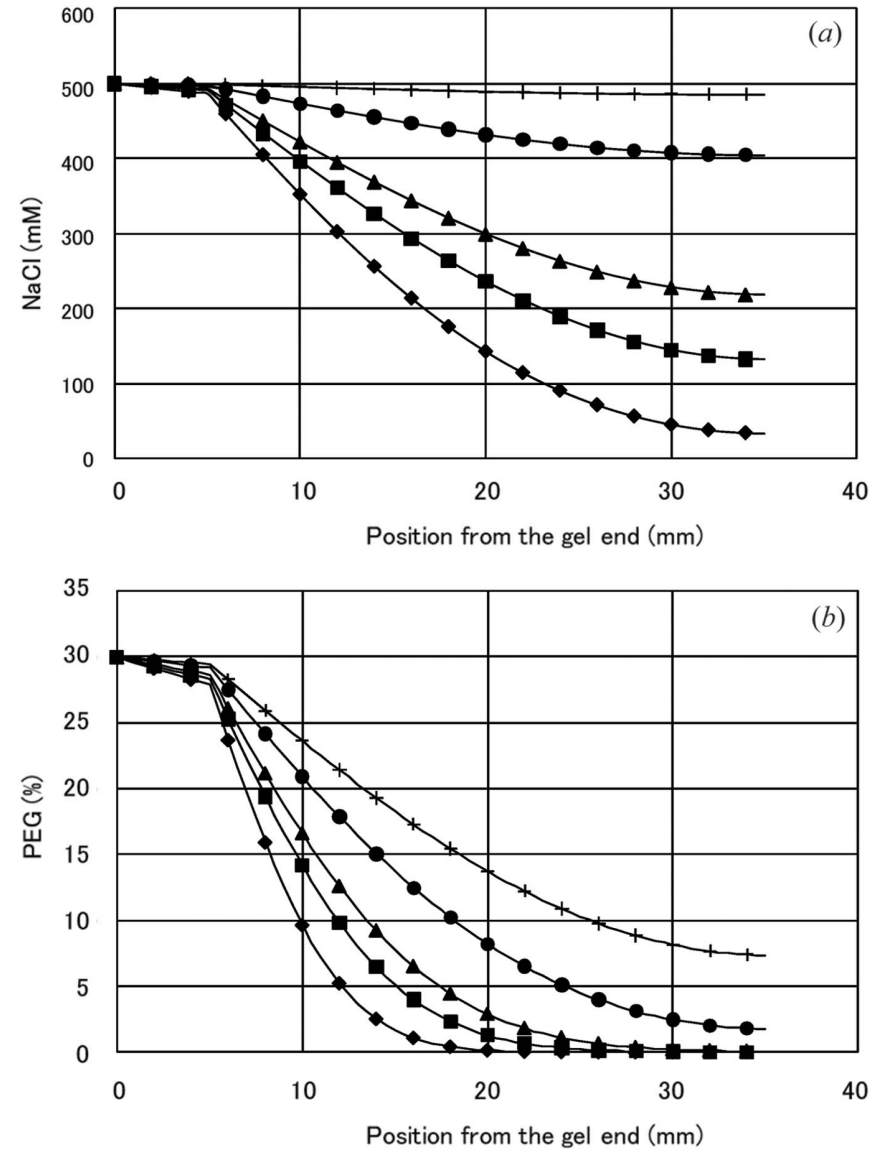

Figure 4

Diffusion profile in a capillary. The results of one-dimensional simulation of the diffusion of $\mathrm{NaCl}(a)$ and PEG $4000(b)$ in the capillary are shown for $500 \mathrm{mM} \mathrm{NaCl}$ and 30\% PEG 4000 as a reservoir solution. The concentrations of these components along the capillary tubing and the gel part are shown. Diamonds: day 1; squares, day 2; triangles, day 3; circles, day 7; plus signs, day 14 .

with $200 \mathrm{mM} \mathrm{NaCl}$ at $\mathrm{pH}$ 9.0. The crystals and precipitate were observed at the position $0-9,0-12,0-18,0-15,0-16$ and $0-$ $15 \mathrm{~mm}$ from the gel-tube site of the capillaries with 200,300, $400,500,600$ and $700 \mathrm{mM} \mathrm{NaCl}$, respectively, at $\mathrm{pH} 7.0$ and at the position $0-3,0-6,0-5,0-5$ and $0-5 \mathrm{~mm}$ from the gel-tube site of the capillaries with $300,400,500,600$ and $700 \mathrm{mM} \mathrm{NaCl}$, respectively, at $\mathrm{pH} 9.0$.

In every case any change emerged between day 14 and two months.

The results of the one-dimensional simulation of $\mathrm{NaCl}$ and PEG 4000 concentration profiles in the capillary are shown in Fig. 4 for the experiment with $500 \mathrm{mM} \mathrm{NaCl}$ and $30 \%$ PEG 4000 as the reservoir solution. The concentrations of these components along the capillary tubing and the gel part at day 1, 2, 3, 7 and 14 after a solution loading are shown. Although the concentration of PEG 4000 does not reach an equilibrium, that of $\mathrm{NaCl}$ almost reaches the concentration in the reservoir at day 14 .

The ionic strengths of the marginal solutions and the charge densities of the proteins were calculated and shown in Tables 1 and 3 . 
Table 3

Comparison of the marginal ionic strength and the calculated charge density. strengths of the reservoir solution were calculated using $\mathrm{p} K_{a}$ values of acetate, HEPES and Tris buffers as $4.80,7.55$ and 8.06, respectively, and the lowest $\mathrm{NaCl}$ concentration in each $\mathrm{pH}$ when crystals are observed. The charge density was calculated using equation (1) with $V_{\mathrm{M}}$ values shown in the table.

\begin{tabular}{|c|c|c|c|c|c|c|c|}
\hline \multirow[b]{2}{*}{$\mathrm{pH}$} & \multicolumn{2}{|l|}{ Lysozyme } & \multicolumn{3}{|c|}{$\alpha$-Amylase } & \multicolumn{2}{|c|}{ Glucose isomerase } \\
\hline & 4.5 & 7.0 & 5.5 & 7.0 & 9.0 & 7.0 & 9.0 \\
\hline Calculated pI & 10.7 & & 4.4 & & & 5.0 & \\
\hline$V_{\mathrm{M}} / \mathrm{PDB}$ code & $2.08 / 1 \mathrm{bwh}$ & & $2.18 / 6 \mathrm{taa}$ & & & 2.78/1xib & \\
\hline $\begin{array}{l}\text { Marginal ionic } \\
\text { strength }(\mathrm{m} M)\end{array}$ & 417 & 311 & 142 & 211 & 205 & 211 & 205 \\
\hline $\begin{array}{l}\text { Calculated charge } \\
\text { density }(\mathrm{m} M)\end{array}$ & 654 & 455 & 265 & 362 & 462 & 268 & 338 \\
\hline
\end{tabular}

The $\mathrm{pI}$ was calculated using $\mathrm{p} K$ values derived from the report of Sillero \& Maldonado (2006). The ionic

ionic strengths. A clear linear relationship, the coefficient of which was $1.61\left(R^{2}=0.76\right)$, was found. Using this relationship the lowest concentration of the salt in the PEG 4000 solution can be predicted prior to performing crystallization experiments, although the $V_{\mathrm{M}}$ value is required. Kantardjieff \& Rupp (2003) reported a plausible $V_{\mathrm{M}}$ value for various proteins, by which we can also predict the salt concentration of a protein which has not yet been crystallized.

Our results can also provide a tip for

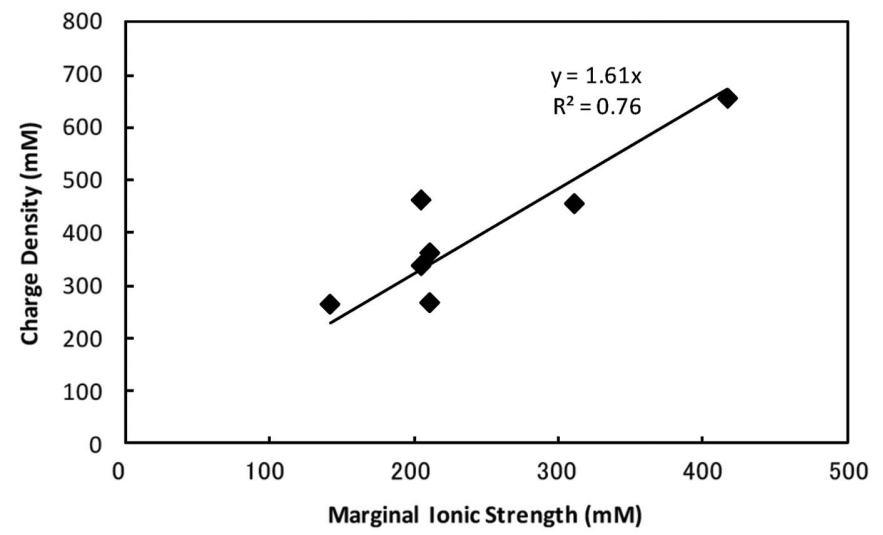

Figure 5

The relationship between the marginal ionic strength of the solution and the charge density of the protein. The coefficient of the linear relationship is $1.61\left(R^{2}=0.76\right)$.

\section{Discussion}

Since the $\mathrm{NaCl}$ concentration mostly reached equilibrium in the capillaries through the counter-diffusion method before day 14 and no change emerged in the capillaries after two months, we can discuss the effect of salt concentration on crystallization. It is commonly said that there is some marginal $\mathrm{NaCl}$ concentration for the emergence of crystals, oil or precipitate. If the concentration is lower, neither crystals, oil nor precipitate would appear. There may be some tendency to obtain oil or precipitate if the concentration of $\mathrm{NaCl}$ is higher.

According to Bonneté (2007), the marginal concentration of $\mathrm{NaCl}$ may have some relation to the electrostatic screen effect. To estimate this effect we used the ionic strength of $\mathrm{NaCl}$ at the lowest concentration when crystals were observed (Table 3). From our calculation the marginal ionic strength increases when the difference between the $\mathrm{pH}$ of the solution and the pI of the proteins is large, which is consistent with the idea of the electrostatic screen effect of a salt. Fig. 5 shows the protein charge density values plotted against the marginal using the vapor-diffusion method. One of the differences between counter-diffusion and vapor-diffusion is the concentration change of salt in a crystallization drop. In the vapordiffusion method a protein solution and a reservoir solution are usually mixed in a drop at a 1:1 ratio. Then crystallization occurs in the drop in which the components are concentrated through water loss. If the original protein and reservoir solution do not have enough salt, the concentration in the drop does not reach the marginal concentration level. If the original protein and reservoir solution has a significant amount of salt, the concentration in the drop easily becomes higher than that in the reservoir solution. Therefore, in the vapor-diffusion method, keeping the salt concentrations neither too low nor too high in the protein solution is important for successful crystallization. In other words, an unsuccessful PEG-based crystallization condition can be changed to a successful one if the salt concentration is well optimized.

This work was supported by JAXA's 'ISS Applied Research Partnership Program'. Many thanks to Professors Atsushi Nakagawa of Osaka University, Yoshiki Higuchi of the University of Hyogo and Sam-Yong Park of Yokohama City University for their helpful advice.

\section{References}

Bonneté, F. (2007). Cryst. Growth Des. 7, 2176-2181.

Chayen, N. E. \& Saridakis, E. (2002). Acta Cryst. D58, 921-927.

Cudney, R., Patel, S., Weisgraber, K., Newhouse, Y. \& McPherson, A. (1994). Acta Cryst. D50, 414-423.

Kantardjieff, K. A. \& Rupp, B. (2003). Protein Sci. 12, 1865-1871.

Matsushima, M. \& Inaka, K. (2007). The 7th Annual Meeting of the Protein Science Society of Japan, Sendai, Japan. 2P-113.

Otálora, F., Gavira, J. A. \& García-Ruiz, J. M. (2009). Prog. Biophys. Mol. Biol. 101, 26-37.

Sillero, A. \& Maldonado, A. (2006). Comput. Biol. Med. 36, 157-166.

Tanaka, H., Inaka, K., Sugiyama, S., Takahashi, S., Sano, S., Sato, M. \& Yoshitomi, S. (2004). J. Synchrotron Rad. 11, 45-48.
García-Ruiz, J. M. \& Moreno, A. (1994). Acta Cryst. D50, 484-490. 